DOI: https://doi.org/10.15407/techned2019.06.065

\title{
IDENTIFICATION AND ASSESSMENT OF THE INFLUENCE OF UNBALANCE VOLTAGE SOURCES IN THREE-PHASE THREE-WIRE ELECTRIC NETWORKS
}

\author{
Journal \\ Publisher \\ ISSN \\ Issue \\ Pages
}

\author{
Tekhnichna elektrodynamika \\ Institute of Electrodynamics National Academy of Science of Ukraine \\ 1607-7970 (print), 2218-1903 (online) \\ No 6, 2019 (November/December) \\ $65-73$
}

\begin{abstract}
Authors
Yu.L. Sayenko ${ }^{1}$, D.N. Kalyuzhniy ${ }^{2 *}$, V.A. Bolgov ${ }^{3 * \star}$

1. Pryazovskyi State Technical University,

str. Universytetska, 7, Mariupol, 87555, Ukraine

2- O.M. Beketov National University of Urban Economy in Kharkiv, str. Marshala Bazhanova, 17, Kharkiv, 61002, Ukraine

3. Estonian Maritime Academy of Tallinn University of Technology, 101, Kopli Street, Tallinn, 11712, Estonia

E-mail: yls62@i.ua, KalyuzhniyDN@gmail.com, victor_bolgov@yahoo.com

* ORCID ID : http://orcid.org/0000-0002-7374-0734

** ORCID ID : http://orcid.org/0000-0001-5268-2291
\end{abstract}

\begin{abstract}
Identification and assessment of the influence of voltage unbalance sources on the power quality is an important task in the relationship between suppliers and consumers of electricity. The method of measurement and evaluation of power quality factors imposes significant restrictions on its decision. For this reason, the existing methods of identification and assessment of the influence of voltage unbalance sources have significant limitations, which make it possible to find acceptable solutions only for the case of one dominant distortion source. A fundamentally new method of solving this problem, focused on the data of one elementary measurement interval of power quality factors is considered in the paper. Simplicity of implementation and high accuracy allow using it without any restrictions on the number and power of distortion sources at the point of common coupling. References 10, figures 4, tables 2.
\end{abstract}


Key words: identification of unbalance voltage source, distribution of actual contributions, point of common coupling, unbalance voltage, power quality.

Received: 06.03.2019

Accepted: 03.07.2019

Published: 25.10.2019

\section{References}

1. Kuznetsov V.G., Shpolianskyi O.G., Yaremchuk N.A. Synthesis Quality of electric energy networks and systems. Tekhnichna Elektrodynamika. 2011. No 3. Pp. 46-52. (Ukr)

2. Electric power quality: monograph. Kharkov: Graf-lks, 2014. 360 p.

3. Shidlovskii A.K., Kuznetsov V.G., Nikolaenko V.G. Economic evaluation of the effects of reducing the quality of electricity in modern power supply systems. Kiev: IED AN USSR, 1981. 49 p. (Preprint 253). (Rus)

4. Sayenko Yu., Kalyuzhniy D. Analytical methods for determination of the factual contributions impact of the objects connected to power system on the distortion of symmetry and sinusoidal waveform of voltages. Przeglad elektro-techniczny. 2015. Vol. 91. Pp. 81-85.

5. Electromagnetic compatibility (EMC). Part 4-30: Testing and measurement techniques. Power quality measurement methods. URL:

https://www.iecee.org/dyn/www/f?p=106:49:0:.::FSP_STD_ID:18768 (accessed 01.09.2019).

6. CIGRE report 468, Review of Disturbance Emission Assessment Techniques, CIGRE/CIRED working group C4.109. 2011. 84 p. URL: https://cigreindia.org/CIGRE\%20Lib/T ech.\%20Brochure/468\%20Review\%20of\%20Disturbance\%20Emission\% 20Techniques.pdf (accessed 01.08.2019).

7. Jayatunga U., Perera S., Ciufo P., Agalgaonkar A.P. Voltage Unbalance Emission

Assessment in Interconnected Power Systems. IEEE Transactions on Power Delivery. 2013. Vol. 28. No 4. Pp. 2383-2393.

8. Jayatunga U., Perera S., Ciufo P. Voltage unbalance emission assessment in radial power systems. IEEE Transactions on Power Delivery. 2012. Vol. 27. No 3. Pp. 1653-1661. DOI: http s://doi.org/10.1109/TPWRD.2012.2196294

9. Renner H. Voltage unbalance emission assessment. 7th International Conference on Electric Power Quality and Supply Reliability

. Estonia, June 16-18 2010. Vol. 16. No 18. Pp. 43-48.

10. Melnikov N.A. Matrix method of analysis of electric circuits. Moskva: Energiia, 1972. 232 p. (Rus) 


\section{PDF}

